\title{
ANALISIS MINAT UMAT BUDDHA DALAM MELAKSANAKAN ATT ThHSIILA PADA SEBULAN PENGHAYATAN DHAMMA DI VIHARA VIRYA JAYALOKA, DESA GEMBONGAN, KECAMATAN PONGGOK, KABUPATEN BLITAR
}

\author{
Oleh: \\ Dwi Ariyanto ${ }^{1}$, Lery Prasetyo $^{2}$, Marjianto $^{3}$ \\ STAB Negeri Raden Wijaya Wonogiri Jawa Tengah \\ dwiariyanto866@gmail.com
}

\begin{abstract}
ABSTRAK
Penelitian ini bertujuan untuk mendeskripsikan minat umat Buddha dan menganalisis faktor-faktor yang mendorong dan menghambat umat Buddha dalam melaksanakan Aț̣asīla pada Sebulan Penghayatan Dhamma. Penelitian ini merupakan jenis penelitian kualitatif dengan pendekatan deskritif. Teknik pengumpulan data dalam penelitian ini mengunakan wawancara, observasi, dan dokumentasi. Sedangkan teknik untuk menguji keabsahan data, yaitu mengunakan teknik triangulasi. Hasil penelitian menunjukan bahwa minat umat Buddha dalam melaksanakan Atthasīla pada sebulan penghayatan dhamma belum maksimal. Fakta yang terjadi banyak umat yang masih enggan datang ke vihara dan melaksanakan Atțasīla. Ada beberapa faktor yang mendorong dan menghambat umat Buddha dalam melaksanakn Ațthasila. Faktor pendorong dalam melaksanakan Atthasìla yaitu niat (cetana), semangat (vīrìya), kesadaran (sati), keyakinan (sadha), rasa malu (hîri), lingkungan, keluarga, dan adanya doorprize. Dengan adanya niat yang kuat mampu mendorong seseorang dalam melaksanakan Ațthasīla. Sedangkan faktor yang menghambat seseorang dalam menjalankan Atțhasila adalah kemalasan, kondisi fisik, teman sebaya, dan acara televisi.
\end{abstract}

Kata kunci: Minat, Ațthasīla, Sebulan penghayatan Dhamma.

\begin{abstract}
This study aims to describe the Buddhist interests and analyze the supporting and inhibiting factors in implementing the Atțasila. This study is qualitative research with descriptive approaches. Data collection techniques use interviews, observation, and documentation. Then the data validity technique uses triangulation. The results of the study show that the interest of Buddhists in implementing Atțhasila in a month of deepening Dhamma is not optimal yet. The fact, many Buddhists reluctant to come to the vihara and implement the Atthasilla. There are the supporting and inhibiting factors that influence the Buddhists in implementing Atțhasīla. The supporting factors are intention (cetana), enthusiasm (vīrīya), consciousness (sati), belief (saddha), shame feeling (hīri), neighborhood, family, and doorprizes. Strong intentions can encourage someone to implement Ațthasìla. Then inhibiting factors are laziness, physical condition, peers, and television programs.
\end{abstract}

Keywords: Interest, Ațthasīla, Deepening Dhamma

\section{PENDAHULUAN}

Puasa dalam masing-masing agama memiliki aturan dan praktik yang berbeda-beda dalam berpuasa, salah satunya dalam agama Buddha. Dalam agama Buddha puasa merupakan perwujudan dari pelaksanaan sīla. Puasa dalam agama Buddha dikenal dengan istilah uposatha/Ațthasīla. Upacara pada hari uposatha sendiri sesungguhnya sudah dilaksanakan oleh umat Hindu pada zaman Buddha, atas saran Raja Bimbisara dan melaksanakan delapan peraturan latihan lainya di Magadha kepada Buddha. Harihari uposatha ini kemudian juga dilaksanakan oleh para bhikkhu maupun umat awam (gharavasa) sampai sekarang (Endro,1997: p.6). Hal ini juga diperkuat dengan permohonan raja Bimbisara yang 
pada waktu itu memohon kepada Buddha yang sedang berdiam di Rajagaha. Permohonan Raja Bimbisara tersebut akhirnya diperbolehkan oleh Buddha. Setelah mendengarkan permohonan Raja Bimbisara, Buddha bersabda sebagai berikut:

"Demikian kejadiannya. Pada suatu waktu Sang Bhagava sedang berdiam di Rajagaha, di puncak karang burung nazar. Pada waktu itu kelana-kelana dari sekte lain mempunyai kebiasaan untuk berkumpul pada waktu pertengahan bulan pada tanggal 14, 15 dan perempatan bulan pada tangal 8 serta berkhotbah tentang Dhamma . Orang-orang berdatangan untuk mendengarkannya. Para umat Buddha semakin menyukai dan semakin mempercayai kelana dari sekte lain itu" (Endro, 1997: pp.5-7).

Berdasarkan dari kutipan diatas disimpulkan bahwa dari sabda sang Buddha. Awal mula Atṭhasīla ketika ada kelana dari sekte lain yang pada pertengahan bulan pada tanggal 14,15 sekte lain tersebut menjalankan delapan latihan kemoralan dan berkhotbah tentang Dhamma. Atṭhasīla merupakan latihan dasar yang seyogyanya dilatih oleh setiap umat dalam mempertahankan kebahagaiaan dan kesuksesan hidup di dunia ini dengan latihan melaksanakan pancasīla Buddhis dan melaksanakan Ațthasīla pada hari tertentu merupakan salah satu pelaksanaan Dhamma. Atțasīla sendiri juga memiliki arti lain yakni berdiam dalam keluhuran dan melakukan kebajikan. Ketika hari uposatha para Bhikkhu dan para Bhikkhuni mengulang kembali Dhamma yang telah diajarkan oleh Buddha Gotama dengan menjalani uposatha-sīla.
Banyak manfaat yang diperoleh dari uposattha ini, jika dilaksanakan dengan sungguh-sungguh. Baik pria maupun wanita akan dapat terlahir di tengahtengah para dewa di alam empat raja besar Apabila para kaum garavasa melakukan uposattha maka, akan mendatangkan kebahagiaan.

Pada hari Atțhasīla umat hanya diperbolehkan makan di pagi hari antara jam 6 sampai jam 7 dan tengah hari sekitar jam 11 siang, atau sebelum matahari melewati jam 12.00 siang. Setelah itu para umat gharavasa bertekad melatih diri untuk menghindari makan makanan setelah lewat jam 12.00 dan melaksanakan delapan peraturan latihan lainya. Meskipun demikian, hal ini tidak berati bahwa selama jangka waktu tersebut umat diperbolehkan makan sesering mungkin. Tetapi kita berusaha untuk menggunakanya semaksimal mungkin.

Banyak hal positif yang didapat apabila, para umat Buddha melaksanakan Atṭhasīla dalam agama Buddha khususnya sekte Theravāda praktik Ațthasīla dimasukan dalam agenda kegiatan Sebulan Penghayatan Dhamma. Melalui kegiatan tersebut, seseorang akan mampu belajar mengendalikan diri, mengurangi kegiatan kurang baik dan selalu menjaga moralitas serta dapat menjaga kestabilan emosinya. Mencoba melakukan Atṭhasīla dalam kegiatan Sebulan Penghayatan Dhamma dapat meminimalisir segala tindakan negatif yang dilakukan. Selain itu, didukung dengan praktik Ațthasīla yang sungguhsungguh dalam Sebulan Penghayatan Dhamma dapat mewujudkan umat Buddha yang memiliki budi pekerti, etika dan moral yang lebih baik.

Aț̣hasila jika dilihat dalam praktiknya hampir sama dengan Pancasila Buddhis, yang dilakukan sehari-hari bagi umat gharavasa yang 
membedakan terdapat pada sīla ke tiga yang berbunyi bertekad melatih diri menghindari perbuatan tidak suci perbuatan tidak suci atau “Abrahmacariya”. Karena selama puasa kita mencontoh hidup seorang brahmana yang hidup tidak berpasangan dimana selama melaksanakan Ațthasila tidak menyentuh pasangan hidupnya. Sedangkan sīla 6-8 adalah sila tambahan untuk penahanan dan latihan pengendalian diri terhadap nafsu keinginan indria, seperti: mata, telinga, lidah, hidung, kulit, dan pikiran.

Salah satu daerah yang mulai menjalankan praktik Ațthasīla dalam sebulan penghayatan Dhamma adalah di Desa Gembongan, Kecamatan Ponggok, Kabupaten Blitar. Tepatnya di Vihara Virya Jayaloka di Vihara Virya Jayaloka terdapat umat Buddha yang sudah mulai menjalankan Atthasīla pada Sebulan Penghayatan Dhamma. Tapi tidak semua umat melaksanakan Atṭhasīla dalam Sebulan Penghayatan Dhamma bisa dibilang belum maksimal. Antusiasme umat dalam melaksanakan kegiatan Ațthasīla dalam Sebulan Penghayatan Dhamma masih kurang. Selain itu juga masih tingginya rasa malas umat akan dalam melaksanakan praktik Atṭhasīla bisa menjadi salah satu faktor mengapa minat umat Buddha dalam menjalankan praktik Atṭhasīla mengikuti praktik Atthhasīla pada Sebulan Penghayatan Dhamma belum maksimal. (Sumber: observasi peneliti dan wawancara dengan bapak Sutrisno ketua Vihara Virya Jayaloka tanggal 23 April 2018)

Faktor pekerjaan juga menghambat umat dalam menjalankan Atṭhasīla dimana rata-rata umat di Vihara Virya Jaya loka bekerja sebagai pekerja berat dan sebagai petani. Dimana pekerjaan ini sangat menguras banyak tenaga sehinga menjadikan kondisi fisik umat mengalami kelelahan dan menjadikan bertambahnya rasa malas dalam menjalankan Atṭhasīla Selain faktor pekerjaan yang cukup mempengaruhi minat umat dalam melaksanakan Atțhasīla faktor teman sebaya juga mempengaruhi dalam pelaksanaan Atthasīla khsususnya bagi para remaja-remaja Buddhis. Dimana rata-rata para remaja lebih memilih untuk bermain dan nongkrong daripada harus datang kevihara dan melaksanakan praktik Ațthasīla Sedangkan bagi ibu-ibu rumah tangga rata-rata kurang berminat melakukan Atțhasīla karena lebih memilih menonton acara televisi. Daripada harus datang ke Vihara dan melaksanakn Atțhasīla Sumber: (Wawancara dengan Romo Meseno tanggal 16 Mei 2018).

Kendala-kendala tersebut semestinya bukan merupakan hal yang menjadi alasan mendasar untuk tidak melakukan praktik Atṭhasīla karena bisa dilihat sangat banyak sekali manfaat yang bisa diperoleh. Tekad yang kuat dan niat yang sungguhsunguh seharusnya menjadi modal utama dalam menjalankan Atṭhasīla. Dampak dari tidak merawat Dhamma dengan baik maka pikiran dan batin akan terkoondisikan untuk berbuat hal-hal yang buruk, Dhamma akan mulai dittingalkan, jika meningal akan meningal dengan tidak tenang. Berdasarkan uraian latar belakang di atas, maka peneliti tertarik untuk melakukan penelitian dengan judul "Analisis Minat Umat Buddha Dalam Melaksanakan Atṭhasilla pada Sebulan Penghayatan Dhamma di Vihara Virya Jayaloka, Desa Gembongan, Kecamatan Ponggok, Kabupaten Blitar.”

Batasan masalah dalam penelitian ini, adalah sebagai berikut: Analisis Minat Umat Buddha Dalam Melaksanakan Atțhasīla Pada Sebulan Penghayatan Dhamma di Vihara Virya Jayaloka, 
Desa Gembongan, Kecamatan Ponggok, Kabupaten Blitar.

Rumusan masalah dalam penelitian ini, yaitu 1) Bagaimana minat umat Buddha dalam melaksanakan Atțhasīla pada Sebulan Penghayatan Dhamma ? 2) Faktor-faktor apa saja yang mendorong dan menghambat minat umat Buddha dalam melaksanakan Aț̣hasīla pada Sebulan Penghayatan Dhamma?

Tujuan penelitian ini adalah 1) Mendeskripsikan minat umat Buddha dalam melaksanakan Atṭhasīla pada Sebulan Penghayatan Dhamma. 2) Menganalisis faktor-faktor yang mendorong dan menghambat minat umat Buddha dalam melaksanakan Atțhasīla pada Sebulan Penghayatan Dhamma.

Adapun teori-teori minat yang penulis ambil dari beberapa ahli, yaitu sebagai berikut :

a. Menurut Suryabrata (2002: p.68) definisi minat adalah "Suatu rasa lebih suka dan rasa ketertarikan pada suatu hal atau aktivitas tanpa ada yang menyuruh". Minat pada dasarnya adalah penerimaan akan suatu hubungan antara diri sendiri dengan sesuatu hal diluar dirinya. Semakin kuat atau dekat hubungan tersebut semakin besar minatnya.

b. Selain itu menurut Menurut Djaali (2009: p.121) minat adalah rasa lebih suka dan rasa ketertarikan pada suatu hal atau aktivitas tanpa ada yang menyuruh. Minat pada dasarnya adalah suatu penerimaan akan suatu hubungan antara diri sendiri dengan sesuatu di luar diri. Semakin kuat atau dekat hubungan tersebut, semakin besar pula minatnya. Minat dapat diekspresikan melalui pernyataan, siswa lebih menyukai suatu hal daripda hal lainnya, dapat pula dimanifestasikan melalui partisipasi dalam suatu aktivitas. Siswa yang memiliki minat terhadap subjek tertentu cenderung memberikan perhatian yang lebih besar pada subjek tersebut.

Berdasarkan kajian teori di atas dapat disimpulkan bahwa minat adalah rasa lebih suka dan ketertarikan pada suatu hal tanpa adanya suruhan. Minat juga merupakan sumber motivasi yang mendorong orang untuk melakukan sesuatu yang mereka inginkan bila mereka bebas memilih. Dan minat juga merupakan suatu perangkat mental yang terdiri dari suatu campuran perasaan, harapan, pendirian, prasangka, dan rasa takut. Karena minat adalah suatu keadaan mental yang menghasilkan respon yang tertarik situasi atau obyek.

Selain itu penulis juga mengambil beberapa teori Atțhasīla dari beberapa ahli, diantaranya adalah:

a. Menurut Rashid (1997: pp.12-40) Uposatha/ Ațthasīla sila berarti suatu aturan yang di dalamnya terkandung sikap batin, penghindaran, pengendalian diri serta patuh pada tatanan yang telah ditetapkan untuk masuk dan berdiam dalam keluhuran.

b. Selain itu, uposatha/ Atthasīla merupakan suatu istilah yang dipakai untuk pelaksanaan upacara keagamaan yang ketat, yang berhubungan dengan menahan diri atau mengendalikan diri. Mengendalikan diri bukan hanya menghindari makan dan minum, tetapi mempunyai pengertian mengendalikan 
diri tidak berbuat sesuatu yang merugikan dirinya sendiri dan orang lain (Mukti, 2003: p.81).

Berdasarkan beberapa uraian maka di atas dapat disimpulkan bahwa Atțasīla adalah suatu bnetuk aturan kemoralan dalam menigkatkan moralitas. Ațthasīla berjumlah delapan sila atau 9 sila bisa dilaksanakan pada hari uposatha maupun hari-hari biasa.

Tidak hanya itu penulis juga memberikan sedikit ulasan terkait dengan Sebulan Penghayatan Dhamma, yaitu sebagai berikut: Sejak tahun 2000 Sangha Theravāda Indonesia membuat sebuah program yang secara khusus diselenggarakan sebulan penuh dalam rangka menyambut datang atau tibanya purnama Waisak untuk dirayakan secara sakral dan meriah setiap tahunnya. Sejak dimulai tahun 2000 hingga sekarang program SPD itu masih tetap diselenggarakan oleh para pengurus vihara-vihara yang tersebar seluruh nusantara Indonesia.

Penyebutan istilah SPD, awalnya Saingha Theravāda Indonesia menggunakan sebutan SPD itu sebagai singkatan dari Sebulan Pendalaman Dhamma. Namun dengan adanya perkembangan situasi dan pengalaman juga adanya perubahan pemahaman terhadap makna kata, maka terjadi juga perubahan istilah itu menjadi SPD adalah singkatan dari Sebulan Penghayatan Dhamma.

\section{METODE PENELITIAN}

Penelitian dengan juduh pengaruh "Analisis Minat Umat Buddha Dalam Melaksanakan Ațthasīla Pada Sebulan Penghayatan Dhamma di Vihara Virya Jayaloka, Desa Gembongan, Kecamatan Ponggok, Kabupaten Blitar" ini menggunakan jenis penelitian kualitatif. Jenis penelitian ini adalah penelitian deskriptif. Sukmadinata (2009: p.18), menyatakan bahwa penelitian deskriptif bertujuan untuk mendefinisikan suatu keadaan atau fenomena secara apa adanya. Metode kualitatif deskriptif merupakan metode penelitian yang menghasilkan data berupa kata-kata tertulis atau lisan dari orangorang dan perilaku yang baru dari pengamatan.

Tempat penelitian dilaksanakan di Vihara Virya Jayaloka, Desa Gembongan, Kecamatan Ponggok, Kabupaten Blitar dilakukan selama kurang lebih enam bulan mulai dari bulan Februari sampai dengan bulan Juli.

Subjek dan Obyek Penelitian dalam penelitian ini, yaitu sebagai berikut :

a. Subjek penelitian adalah tempat untuk mendapatkan informan secara spesifik. Informan adalah orang yang memberikan informasi situasi dan kondisi latar (lokasi atau tempat) penelitian (Moleong dalam Prastowo, 2014: p.195). Subjek yang dimaksud dalam penelitian ini adalah umat Buddha, ketua vihara, romo pandita yang menjadi informan dalam penelitian peneliti di Kecamatan Ponggok, Kabupaten Blitar.

b. Menurut Ratna (2010: p.12), “objek adalah keseluruhan gejala yang ada di sekitar kehidupan manusia". Obyek penelitian dalam kegiatan ini adalah kegiatan Sebulan Penghayatan Dhamma yang dilakukan di Kecamatan Ponggok, Kabupaten Blitar. Penelitian ini menggunkan dua data, yaitu data primer dan data sekunder yakni dengan melakukan wawancara kepada romo pandita yang ada di Kecamatan Ponggok. Berdasarkan hasil wawancara yang dilakukan peneliti maka, akan 
dikembangkan sesuai dengan kemampuan peneliti. Sedangkan data sekunder berupa buku-buku dan sumber sumber tertulis.

Teknik pengumpulan data yang digunakan dalam penelitian ini adalah :

a. Wawancara (Interview), ialah percakapan yang dilakukan oleh dua orang atau lebih dengan maksud tertentu yang dilakukan oleh dua pihak yaitu pewawancara (interview) sebagai penanya dan terwawancara (interviewee) sebagai pemberi jawaban (Moleong, 2007: p.186). Selain itu, wawancara digunakan untuk mengumpulkan data primer dan informasi akuratif yang lebih banyak dan menjalani wawancara langsung kepada responden. Dalam hal ini yang menjadi responden adalah para pemuda dan para romo pandita yang dilakukan pada tanggal 25 Mei 2018, 26 Mei 2018, 29 Mei 2018, 03 Juni 2018, 05 Juni 2018.

b. Observasi (Observation), menurut Nasution dalam Sugiyono (2014: p.310) menyatakan bahwa, observasi adalah dasar semua ilmu pengetahuan. Para ilmuan hanya dapat bekerja berdasarkan data, yaitu fakta mengenai dunia kenyataan yang diperoleh melalui observasi. Data itu dikumpulkan dan seiring dengan bantuan berbagai alat sehingga, keadaan yang berada di lapangan dapat diobservasi dengan jelas. Dalam hal ini yang menjadi tempat untuk melakukan observasi adalah umat Buddha yang berada di Vihara Virya Jayaloka Kecamatan Ponggok, Kabupaten Blitar. Observasi dilakukan tanggal $05 \mathrm{Mei}$
2018, 13 Mei 2018, 14 Mei 2018, 15 Mei 2018, 16 Mei 2018, 20 Mei 2018

c. Dokumentasi, adalah suatu teknik pengumpulan data dengan melihat dan menganalisis dokumen-dokumen yang dibuat yang berkaitan dengan penelitian. Studi dokumentasi merupakan salah satu cara yang dapat dilakukan oleh peneliti kualitatif untuk mendapatkan gambar dari sudut pandang subjek yang bersangkutan (Herdiansyah, 2013: p.143). Melalui metode ini, penulis dapat mengetahui gambaran masyarakat, jumlah umat Buddha, dan aturan berkaitan dengan Ațthasīla pada Sebulan Penghayatan Dhamma. Selain itu dokumentasi dokumentasi berupa foto kegiatan Atthasila yang dilakukan oleh umat Buddha Vihara Virya Jayaloka sebagai bukti bahwa informasi yang digunakan benar-benar valid

Keabsahan data yang digunakan dalam penelitian ini adalah dengan uji triangulasi, yaitu sebagai berikut:

a. Trianggulasi adalah cara yang paling umum digunakan dalam penjaminan validitas data dalam penelitian kualitatif. Trianggulasi merupakan teknik pemeriksaan keabsahan data dengan memanfaatkan sesuatu yang lain diluar data itu untuk keperluan pengecekan data atau sebagai pembanding terhadap data itu. Menurut Sugiyono (2014: p.267), Validitas merupakan "derajat ketetapan antara data yang terjadi pada objek penelitian dengan daya yang dapat dilaporkan oleh peneliti” 
b. Sugiyono (2014: pp.273-274), menjelaskan ada tiga macam triangulasi. Ketiga triangulasi tersebut antara lain: triangulasi sumber, pengumpulan data, dan waktu. 1) Triangulasi sumber adalah trianggulasi yang digunakan untuk menguji kredibilitas data dengan cara mengecek data yang telah diperoleh melalui beberapa sumber. 2) Triangulasi teknik adalah suatu alat untuk menguji kredibilitas data dengan cara mengecek data yang sama namun dengan alat yang berbeda. 3) Triangulasi waktu adalah triangulasi yang sering mempengaruhi data. Data yang dikumpulkan dengan teknik wawancara dipagi, siang, maupun malam hari akan memberikan data yang lebih valid sehingga lebih kredibel.

Teknik analisis dalam penelitian ini mengambil dari teori Nasution dan Miles serta Huberman, yaitu sebagai berikut:

Nasution, (2003: p.34) menyatakan analisis telah mulai sejak merumuskan dan menjelaskan masalah, sebelum terjun di lapangan dan berlangsung secara terus sampai hasil penelitian namun, dalam penelitian kualitatif, analisis data lebih difokuskan selama proses di lapangan bersamaan dengan pengumpulan data.

Langkah-langkah analisis data menurut Miles dan Huberman dalam Sugiyono (2014: p.337 ) adalah sebagai berikut: 1) Pengumpulan data, yaitu mengumpulkan data di lokasi penelitian dengan melakukan observasi, wawancara dan dokumentasi dengan menentukan strategi pengumpulan data yang dipandang tepat dan untuk menentukan fokus serta pendalaman data pada proses pengumpulan data berikutnya. 2) Reduksi data, yaitu sebagai proses seleksi, pemfokusan, pengabstrakan, transformasi data kasar yang ada di lapangan langsung, dan diteruskan pada waktu pengumpulan data, dengan demikian reduksi data dimulai sejak peneliti memfokuskan wilayah penelitian. 3) Penyajian data, yaitu rangkaian organisasi informasi yang memungkinkan penelitian dilakukan. Penyajian data diperoleh berbagai jenis, jaringan kerja, keterkaitan kegiatan atau tabel. 4) Penarikan kesimpulan, yaitu dalam pengumpulan data, peneliti harus mengerti dan tanggap terhadap sesuatu yang diteliti langsung di lapangan dengan menyusun polapola pengarahan dan sebab akibat.

\section{HASIL DAN PEMBAHASAN}

Minat umat Buddha dalam menjalankan Ațthasīla mengalami perkembangan dari tahun ke tahun. Umat yang menjalankan Ațthasīla rata-rata dari golongan usia 30 sampai 60 tahun yang mempunyai minat cukup tinggi dalam menjalankan Atțhasīla. Sedangkan untuk usia para remaja masih terlihat sedikit dalam menjalankan praktik Atțhasila .

Hasil penelitian menunjukan bahwa faktor pendukungnya antara lain Niat (Cettana), Rasa Malu (Hirri), Kesadaran (Sati), Keyakinan (Saddha), empat faktor tersebut merupakan faktor dari dalam diri seseorang dalam menjalankan Atțhasīla. Sedangkan faktor pendukung dari luar yaitu lingkungan, keluaraga, dan dengan adanya doorprize atau reward. Sedangkan faktor yang menghambat umat dalam menjalankan Ațthasīla adalah, Rasa malas, Kondisis fisik, dua hal itu merupakan faktor penghambat dari dalam. 
Sedangkan faktor penghambat dari luar yaitu Pengaruh teman sebaya, Acara televisi, Pekerjaan, Lingkungan. Dari beberapa faktor inilah yang mendorong dan menghambat umat dalam melaksanakan Aț̣hasīla.

\section{KESIMPULAN}

Berdasarkan hasil dan pembahasan penelitian, maka dapat disimpulkan sebagai berikut :

Minat umat Buddha dalam menjalankan Atṭhasīla mengalami perkembangan dari tahun ke tahun. Umat yang menjalankan Atṭhasīla rata-rata dari golongan usia 30an sampai 60an tahun yang mempunyai minat cukup tinggi dalam menjalankan Aț̣hasīla. Sedangkan untuk usia para remaja masih terlihat sedikit dalam menjalankan praktik Aț̣hasīla.

Faktor pendukungnya antara lain Niat (Cetana), Rasa Malu (Hīri), Kesadaran (Sati), Keyakinan (Saddha), Semangat(Vīrīya) lima faktor tersebut merupakan faktor dari dalam diri seseorang dalam menjalankan Ațthasīla. sedangkan faktor pendukung dari luar yaitu lingkungan, keluaraga, dan dengan adanya doorprize atau reward. Sedangkan faktor yang menghambat umat dalam menjalankan Aț̣hasīla antara lain, rasa malas, kondisi fisik, dua hal itu merupakan faktor penghambat dari dalam. Sedangkan faktor penghambat dari luar yaitu pengaruh teman sebaya, acara televisi, pekerjaan, lingkungan. Dari beberapa faktor inilah yang mendorong dan menghambat umat dalam melaksanakan Ațthasìla.

\section{DAFTAR PUSTAKA}

Djaali. (2007). Psikologi Pendidikan. Jakarta: Bumi Aksara.

Endro, Herman S. (1997). Hari raya umat Buddha dan kalender Buddhis. Jakarta: Yayasan Dhammadipa Arama.

Herdiansyah, Haris. (2010). Metodologi Penelitian Kualitatif. Jakarta: Salemba Humanika

Moleong, Lexy J. (2007). Metodologi Penelitian Kualitatif. Bandung: PT Remaja Rosda Karaya.

Mukti. Krishmanda Wijaya (2003). Berebut Kerja Berebut Surga. Jakrta: Yayasan Dharma Pembangun.

Nasution. (2003). Metode Penelitian Naturalistik Kualitatif. Bandung: Tarsito.

Rashid Teja S M. (1997). Sila Dan Vinaya. Jakarta: Buddhis Bodhi.

Ratna, Nyoman Kutha. (2010). Metodologi Penelitian: Kajian Budaya dan Ilmu Sosial Humaniora Pada Umumnya. Pustaka Pelajar : Yogyakarta.

Sugiyono. (2014). Memahami Penelitian Kualitatif . Bandung: Alfabeta.

Sukmadinata, Nana Syaodih. (2009). Metode penelitian Pendidikan. Bandung: Remaja Rosdakarya.

Suryabrata, Sumadi. (2002). Psikologi Pendidikan . Jakarta: PT. Grafindo Perkasa Rajawali. 